\title{
The Demographic Variables and Emotional Intelligence as Correlates of Work Values: A Cross-Cultural Examination towards Organizational Change
}

\author{
Rommel Pilapil Sergio, Antonette Lazaro Dungca, and Luzelle Anne Gonzales-Lim Ormita
}

\begin{abstract}
This research paper is a cross-cultural study of demographic variables and their role on emotional intelligence and work values among 437 purposively selected call center representatives (CSRs) from the Middle East, Iran, Pakistan, Russia, India, and the Philippines. The paper aims to establish a baseline literature on the link between demographic variables (such as gender, civil status, work time schedule, and nationality) on emotional intelligence and work values that leads to the appropriate conceptualization of organizational change programs. The descriptive, comparative-correlational methods were employed as this paper also threshes out whether CSRs differ on emotional intelligence and work values based on demographic characteristics. The researchers utilized three instruments such as Demographic Profile Sheet, Emotional Competence Inventory, and Work Values Inventory. The general findings confirm that there is a significant relationship between emotional intelligence (particularly on the clusters of self- management, social awareness and relationship management) and work values (specifically in the areas of management, achievement, supervisory relations, way of life, and independence). In line with the results, the organizational change programs with emphasis on diversity management have been introduced to set future directions for organizations in call center organizations involved in the study.
\end{abstract}

Index Terms-Demographic variables, emotional intelligence, organizational change, work values.

\section{INTRODUCTION}

Business Processing Organizations (BPO) known as call centers are tools for organizing communication with customers with the help of telecommunication (Zapf, et al.) [1]. In line with this, Russell [2] said that since the appearance of call centers in the 1990s, they have become the most important single source of customer contact in the developed economies and have become huge income generators. Over the past decade, call centers have become a central element in the way information services are produced and delivered to the public.

Call centers may be part of the company or otherwise referred to as "in-house" call center. But there are call centers which provide external services for other companies and they are known as "service bureau". Likewise, call centers may either be inbound or outbound. Inbound call centers are restricted to a passive role like handling customers who call if they have questions or complaints concerning products they bought or services they availed. On the other hand, outbound

Manuscript received August 1, 2013; revised November 10, 2013.

Rommel Pilapil Sergio is with the Canadian University of Dubai, United Arab Emirates (e-mail: rommel@cud.ac.ae). call centers engage in phoning up people such as in telemarketing [1].

Since early 2000, BPOs attracted new Filipino fresh graduates because of its above minimum wage rates, cool co-workers, hefty signing bonus, and other perks and BPO work has also become an option against the choice to migrate to another country for a more competitive salary package. But still, the salaries of Filipino call center employees are comparatively lower globally considering their command of the English language and their ability to copy Western culture, which are the reasons why foreign companies are outsourcing their services in the Philippines. A Watson-Wyatt study in 2009 even mentioned that despite the supposed high salaries of Filipino call center agents (as compared to the minimum wage earner in the Philippines), they can only out-earn their American counterparts by 2037. Much more, Salamat [3] said that BPOs have taken measures to cut costs by slashing on their salary budget for increases, reducing paid hours such as overtime, streamlining or reducing the number of people per team without correspondingly reducing the expected output, putting employees on extended leave or terminating employees. The Philippine BPO industry has been positioning itself as the "preferred destination for outsourcing," However, the fact remains that it still gets mainly the low end of the business process outsourcing jobs [3]. As compared to the salaries of call center workers in other countries like in India, Thailand, Malaysia or Singapore, salaries received by Filipino call center workers are much lower.

Call center work has a very high degree of structural division of labor which contributes to simplified tasks. Job simplification comes along with repetitive and routine work that contributes to low utilization of qualifications, including knowledge, skills and abilities. Thus, call center work, particularly those in front line and inbound jobs is described as possessing the characteristics of Taylorism due to limited job demands, low complexity, low variability and low control [4].

Work in call centers is indeed a stressful experience as evidenced by the high rate of turnover and absenteeism. CSRs' short-cycle routine interactions with customers which are controlled by automatic call distribution systems give them little control of when to speak to customers and who of them will they speak to [1], and the number of calls they receive [5].

CSRs follow conversational rules that specify the way they present themselves to customers, including a fixed format for the introduction and closure of a call [5]. Their work 
invariably involves a high degree of personal contact and the continuous need to interpret and shape the expectations of service recipients Deery, et al. [5].

Knowing the difficulties being faced by CSRs in today's workplace, the researchers of the study have hypothesized the role of demographic variables and emotional intelligence on work values.

Emotional intelligence is comprised of competencies about job skills that can, and indeed, must be learned. An underlying EI ability is necessary, though not sufficient, tomanifest competence in any one of the EI domains, or clusters. A person may be highly empathic yet poor at handling customers if he or she has not learned competence in customer service. Although one's emotional intelligence determines potential for learning the practical skills that underlie the EI clusters, one's emotional competence shows how much of that potential he/she has realized by learning and mastering skills and translating intelligence into on-the-job capabilities according to Goleman [6].

In different scenarios stated above about CSR challenges, emotional intelligence is vital but work values among employees matter as well in terms of job retention. Conceptualizations of values also emphasize behavior. Donald Super [7] defined work values as "an objective, either a psychological state, a relationship, or material condition, that one seeks to attain". Schwartz [8] offers a more specific definition of values indicating that values are "desirable states, objects, goals, or behaviors, transcending specific situations and applied as normative standards to judge and to choose among alternative modes of behavior". This definition highlights the common agreement that values are generalizable across situations despite research that suggests individuals' values do change slightly over time [9] In a study by Selmer and De Leon [10] on organizational "acculturation" shows that multinational corporations can play a role in the transmission of values. It would be of theoretical interest for researchers to further examine this issue of interconnectedness and causality, and to contrast the two ways in which general and work values may influence each other. It is important to note that in modern societies work values are typically considered as salient, basic, and influential. This is clearly demonstrated by research on "work centrality" carried out in the context of the Meaning of Working project [9], [11], as well as the Work Importance Study [12]. The importance of the work role in many cultures makes work values into core values that take a cardinal position in the overall pattern of values. Finally, something should be said about values in relation to work activity - in this case, the CSRs'.

Several studies have pointed that the demographic variables raised in this study are related to both emotional intelligence and work values. However, there is a need to provide baseline literature that provides a link between emotional competence and work values.

Looking into specific theories related to both variables emotional competence and work values, it can be assessed that their areas (or clusters, dimensions) are similar at many extent.

\section{REVIEW OF RELATED LITERATURE}

\section{A. On Demographic Variables and Emotional Intelligence}

Emotions are an essential tool for successful and fulfilling life if used properly. In day-to-day life, emotions affect relations with other people as well as one's self-identity and ability to complete a task. To put this in proper context, Goleman popularized the concept of emotional intelligence which refers to the capacity for recognizing one's own feelings and those of others, for motivating ourselves and for managing emotions effectively in ourselves and others. An emotional competence is a learned ability that is grounded in emotional intelligence that contributes to effective performance at work [13].

In the business world, professionals believed to leave their emotional baggage at home and this emotional plug can ultimately lead to personal consequences [14].

The importance of emotions in workplace has been established by many scholars. As they have investigated the explanations of emotional intelligence in organizational environment in classical management theory and practice to understand the abilities of human being. Over three decades of psychological assessment intervention and research has justified the importance of taking social and emotional competencies into consideration when attempting to predict occupational effectiveness. Cherniss and Goleman [15] concluded that interventions targeted at EI-based competencies are effective and tend to enhance such desired outcomes as self-awareness and rapport.

Emotional intelligence (EI) has been claimed to validly predict a variety of successful behaviors of human being at workplace [16]. Further, it is suggested that EI is necessary for recruitment policies and decisions in various organizational activities. Various studies show a correlation between high levels of EQ and high levels of performance. People with high EQ are more grounded, more resilient and are more satisfied at work. Indeed individuals with higher than average EQ display strong self-awareness and high levels of interpersonal skill as explained by Chermiss and Goleman [15]. In terms of correlating demographic profile with emotional competence of 134 plant supervisors, Sergio [17] found out that civil status significantly relate with the four clusters of emotional competence but not with age, educational attainment, and work tenure.

EI, a multi-dimensional construct that links emotion and cognition with the aim of improving human interactions in their activities has been linked to improved workplace behavior Aritzeta, Swailes \& Senior as cited in Allam [14].

Many organizations today look at EI among the employees even before hiring them to run the organization effectively. EI is useful in situations and environments purely for the fact that emotional competencies initiate, motivate, and persuade individuals. Finally there is strong relationship between emotional intelligence and various organizational variables such as job satisfaction, job performance, quality of life, interpersonal relationships, job quality, job involvement and management of occupational stress.

In line with the baseline literature above, the alternative hypothesis below has been drawn: 
H1: There are significant differences in the emotional intelligence of the CSRs when grouped according to gender, civil status, work time schedule and nationality.

\section{B. On Demographic Variables and Work Values}

Values are defined as the basic convictions about what are personally or socially preferred modes of conduct or goals according to Rokeach [18], as cited in Lu and Lin [7]. There are various classifications such as those of Wray-Lake, Svertsen, Briddel, Osgood and Flanagan [19] to include: importance of work; work that allows time for leisure; job security; extrinsic rewards; materialism; and intrinsic rewards. Super's [20] work highlights 15 work values specified as: achievement, management, aesthetics, prestige,altruism, security, associates, supervisory relations, creativity, surroundings, economic returns, variety, independence, way of life, and intellectual stimulation. Ross, Schwartz, and Surkiss [21] argue that despite a plethora of different labels, most work researchers appear to identify the same two or three types of work values: intrinsic or self-actualization values; extrinsic or material values; and social or relational values. They add a fourth distinctive type of work values that parallels the basic self-enhancement higher value type. This type of work values, like self enhancement, should be concerned with prestige or power.

Wray-Lake, et al. [19] define extrinsic work values as those that put importance to a job "that has high status and prestige", "that most people look up to and respect", "where the chances of advancement and promotion are good", and "which provides you with a chance to earn a good deal of money". These values, according to Ross, et al. [21], express conservation values. As they put it, job security and income provide workers with the requirements needed for general security and maintenance of order in their lives. On the other hand, intrinsic work values as Wray-Lake, et al. [19] explain put importance to a job that "is interesting to do", "uses your skills and abilities", lets you do things you can do best", "where you can see the results of what you do", "where you can learn new things, new skills", and "where the skills you learn will not go out of date". In addition, Ross et al. [21] define intrinsic work values as values that directly express openness to change values - the pursuit of autonomy, interest, growth, and creativity in work. Social or interpersonal work values are those that express the pursuit of self-transcendence values - where work is seen as a vehicle for positive social relations and contribution to society. The fourth set of values referred to as prestige values points to a job that provides authority to make decisions over people, is prestigious and highly valued.

The differences in work values across categories at country, organizational and individual levels are investigated once values have been defined as stated by Roe and Ester [22]. The typical approach is to produce profiles of coordinates, showing the mean scores of various entities on a number of value dimensions. A theoretical assumption is posited that a particular relationship exists between the different elements of the profile, making it into a value pattern. Roe and Ester [22] underscore that research studies with a sociological origin typically look for differences in the natural environment, economic circumstances and religion as explaining factors. The demographic profile for this study looks into statistical characteristics of young professionals in the UAE. The study would examine six demographics, namely: age, sex, nationality, educational attainment, civil status and tenure of employment. Such profiling would help in making generalizations about patterns of work values across groups of young professionals.

Sta. Ana, Frega, and Sergio [23] conducted a study of 210 respondents from private and public sectors in the United Arab Emirates (UAE). A descriptive-correlation research design was used to specifically explore the relationship of work values and the demographic profile of the young professionals. The findings showed that work values of the respondents in the Middle East and East Asian samples vary. Work value, such as Way of Life has a significant relationship with educational attainment; whereas, work values such as Surroundings, Variety, and Altruism have significant relationship with age, gender, and civil status. Furthermore, work values such as Achievement, Supervisory Relationship, Way of Life, Associates, Aesthetic, Prestige and Altruism is significantly associated with nationality. In conclusion, the study revealed that Achievement and Way of Life are the most dominant work values of the young professionals in the UAE. Furthermore, nationality is also an influential factor of work values among respondents.

Related studies on work value patterns have looked into differences by gender, race, parents' education and adolescents' college aspirations as in Wray-Lake, et al. [19] among American high school seniors. Lu and Lin [7] studied the profile of Taiwanese workers in his study. Cultural differences captured by nationality has been studied fairly well as in Kwon [24] in his study on work values among Korean, British, and American multinational banks in Korea; and Rahman [25] on work values in Malaysia and Thailand.

On values and demographics, the study among American high school seniors from 1976 to 2005 by Wray-Lake, et al. [19] noted gender differences across items. Furthermore, males expressed greater support for extrinsic work values, whereas females reported more support than males for intrinsic work values. Admittedly, the study says that the findings are consistent with work, as cited in Schulenberg et al [9] and they fit with broader values literature wherein females consistently show a stronger orientation towards intrinsic pursuits and care orientations and males are more extrinsically-oriented.

In "Understanding the importance of work" [26], the study showed that working men attach greater importance to normative values than working women do; and that working women attach greater importance to individualistic values than men do. It cites a similar study by Karakitapoğlu Aygün and Đmamoğlu [27] on the values of university students which reveal that women attach greater importance to universal values than men; and that men attach greater importance to normative values than women.

Work values may be the same or different among groups of individuals and there are various explanations to these. Meglino and Ravlin [28], has taken one suggestion derived from the belief that values are "founded, in part, upon the fundamental biological similarities of all human beings". 
In specific studies such as Kwon's [24] regression analysis shows that education had a significant but negative impact on individualism, indicating that employees with a higher level of education have a more collectivistic work value than those with a low level of education. Interestingly, Kwon's [24] study of work values of multinational banks in Korea and multinational employees conclude that the work values of multinational employees in Korea are determined by the demographic factors rather than by a firm's nationality factor.

Lu and Lin's [7] correlation analysis shows demographic relationships. They found out that employees with higher levels of formal education, longer seniority and higher income levels tended to perceive their current jobs more favorably in terms of material gratification. Zytowski [29] said that Super's work values inventory noted that certain effects are revealed by age and gender breakdowns. Overall, almost all medians decline with increasing age. Security shows the greatest decline with increasing age. Although males rate Supervision, Achievement, Variety andWorkplace as more important than do females, females rate creativity more important than do males.

Wray-Lake, et al. [19] noted that the six values they assessed over time evidenced level differences by demographic characteristics and that only trends in the value for new and adaptable work skills showed differential change over time for respondents with different college aspirations.

Zytowski [29] found a number of differences in mean scores for various respondent characteristics on certain work values inventory scales. It was revealed that increasing age was associated with declines on scores on Co-workers, Lifestyle, Prestige, Security and Workplace. Females give greater weight to Lifestyle, Supervision, and Workplace than males. Blacks valued Co-workers and Security more than both Hispanics and Whites, and Creativity, Income and Workplace more than Whites.

In the light of the body of foregoing information, the alternative hypothesis below has been drawn:

$H 2$ : There are significant differences in the work values of the CSRs when grouped according to gender, civil status, work time schedule and nationality.

\section{Emotional Intelligence Vis-à-Vis Work Values: \\ Theoretical Constructs}

Goleman [6] has set out a theoretical framework of emotional intelligence (EI) that reflects how an individual's potential for mastering the skills of Self-Awareness, Self-Management, Social Awareness, and Relationship Management translates into on-the-job success. This model is based on EI competencies that have been identified in internal research at hundreds of corporations, educational institutions, and organizations as distinguishing outstanding performers. Focusing on EI as a theory of performance, it looks at the physiological evidence underlying EI theory, and it reviews a number of studies of the drivers of workplace performance and the factors that distinguish the best individuals from the average ones.

On another hand, the theory and research on work values by Roe and Ester [22] precede largely from the premise that it is derived from people's basic value systems that help them navigate through the multiple spheres of their lives. An early definition by Rokeach [18] states that a value is an enduring belief that a specific mode of conduct or end-state of existence is personally or socially preferable to an opposite or converse mode of conduct or end-state of existence for Uyguç [30]. Rokeach [18] defined beliefs about preferable modes of conduct 'instrumental values' and beliefs about preferable end-states 'terminal values'. In a value system, individuals rank-order their instrumental and terminal values along a continuum of importance. Work values on the other hand are more specific than general life values as they apply to a specific life domain. As such, according to Šverko [12] work values influence the importance of work in the life of the individual.

The theories laid out above points to internal (emotional) state driven outwardly as one deals with people in any organization; whereas, the manifestation of behavior (internal and external values system) is treated as a separate circumstance. Linking the two theoretical constructs would establish a baseline literature on emotional intelligence and work values. In this light, the researchers postulated the alternative hypothesis:

H3: There is a significant relationship between the emotional intelligence and work values of the CSRs.

\section{Methodology}

A total of 437 purposively selected CSRs in Dubai and the Philippines representing different nationalities, namely: Middle East (Egyptian, Emirati, Syrian, Palestinian, Jordanian, Omani, and Iraqi), Iran, Pakistan, Russia, India and the Philippines were included in this study.

The Demographic Profile Sheet, Emotional Competence Inventory (ECI) and the Work Values Inventory (WVI) were the research instruments used to gather demographic characteristics, emotional intelligence and work values data, respectively. The Demographic Profile Sheet includes data such as gender, civil status, work time schedule, and nationality.

The ECI, as explained by Wolff [13] measures 18 competencies identified by Dr. Daniel Goleman in 1998 that are organized into four clusters: Self-Awareness (knowing one's internal states, preferences, resources, and intuitions; it contains three competencies: emotional awareness, accurate self-assessment and self-confidence), Self-Management (refers to managing ones' internal states, impulses, and resources; it contains six competencies: emotional self-control, transparency, adaptability, achievement, initiative, optimism), Social Awareness (how people handle relationships and awareness of others' feelings, needs, and concerns; this contains three competencies: empathy, organizational awareness, and service orientation), and Relationship Management (the skill or adeptness at inducing desirable responses in others; this cluster contains six competencies: developing others, inspirational leadership, change catalyst, influence, conflict management, teamwork and collaboration).

On the other hand, the revised Work Values Inventory developed by Dr. Donald Super [20] includes 15 work values scales-Altruism, Variety, Creativity, Way of Life, Security, 
Associates, Aesthetic, Prestige, Management, Achievement, Surroundings, Social Relations, Economic Reasons, Intellectual Stimulation, and Independence.

Descriptive statistics were employed to provide quantitative descriptions of the respondents' demographic characteristics such as frequency and percentages distribution and the profile of the respondents in terms of data on emotional competence and work values. To determine respondents' differences when grouped according to their demographic characteristics on these variables, the t-test independent and one-way ANOVA were used accordingly. Pearson's $r$ was utilized to determine the correlation between emotional competence and work values.

\section{RESUlTS AND DisCUSSION}

The purpose of this study is to provide baseline literature on the role of emotional competence on work values among CSRs. In addition, the interplay of these two variables on a number of demographic characteristics is also revealed.

\section{A. The Demographic Profile of the CSRS}

CSRs are mostly female $(69.8 \%)$, single $(68 \%)$ with more than $50 \%$ of the respondents that represent the United Arab Emirates. Most of the respondents follow real time work schedule $(53.8 \%)$.

\section{B. Differences on Emotional Intelligence Based on Demographic Variables}

Table I shows the differences on emotional intelligence based on demographic variables. There are gender differences on overall emotional competence but not in any of the four clusters of emotional intelligence. The literature shows mixed data of information in terms of gender differences on emotional intelligence. Some studies found significant differences among male and female while other studies found otherwise. The result of this study is supported by Pande [31] as he concluded that there were significant differences in the emotional intelligence mean scores of male and female workers in organizations. He further found that female prospective teachers had higher level of emotional intelligence than their male counterparts. In a study of 358 managers, Cavallo and Brienza [32] found some gender differences when rated by supervisors and no differences were found between them by self-rating.

TABLE I: DIFFERENCES ON EMOTIONAL INTELLIGENCE BASED ON DEMOGRAPHIC CHARACTERISTICS

\begin{tabular}{lllllll}
\hline $\begin{array}{l}\text { Demo. } \\
\text { Variable } \\
\text { s }\end{array}$ & $\begin{array}{l}\text { Self } \\
\text { Aware. }\end{array}$ & $\begin{array}{l}\text { Self } \\
\text { Mng't. }\end{array}$ & $\begin{array}{l}\text { Social } \\
\text { Awar } \\
\text { e. }\end{array}$ & $\begin{array}{l}\text { Rel. } \\
\text { Mng' } \\
\text { t. }\end{array}$ & $\begin{array}{l}\text { EI } \\
\text { Over } \\
\text { all }\end{array}$ \\
\hline Gender & $T$ & 1.949 & 1.937 & 1.782 & 1.651 & 2.345 \\
& $p$ & .052 & .053 & .075 & .099 & .019 \\
Civil & $T$ & 1.067 & 1.771 & 2.207 & 2.125 & 2.286 \\
Status & & & & & & \\
& $p$ & .286 & .077 & .028 & .034 & .023 \\
Work & $T$ & 1.133 & 1.704 & 2.943 & 3.262 & 2.911 \\
Sched & & & & & & .003 \\
Nationali & $F$ & 1.221 & 1.055 & 4.056 & .485 & .806 \\
ty & & & .258 & .089 & .001 & .004 \\
& $p$ & .298 & .385 & .001 & .787 & .546 \\
\hline \hline
\end{tabular}

On Social Awareness, Relationship Management and overall emotional intelligence, CSRs differ when grouped according to civil status and work time schedule. Only in Social Awareness cluster, however, that there is a significant difference among CSRs based on nationality. Based on these findings, it can be said that single and married CSRs differ on how they handle relationships as well as their level of awareness of other's feelings, needs and concerns. Likewise, CSRs' work time schedule and nationality seem to contribute to differences in the way they handle relationships and their awareness of others' feelings and perspectives. The same result has been found in terms of the CSRs' skills or adeptness at inducing desirable responses in others. Single and married CSRs differ in this aspect in the same manner as those CSRs working on real and opposite time. Russians, on the other hand, were found to be emotionally aware, self-confident, and capable of assessing the self accurately as well as good at managing the self. In the study conducted by Ealias and George [33], they found that there is a significant difference on the emotional intelligence between married and unmarried respondents. In another study, Pande (2010) [31] said married prospective teachers had higher level of emotional intelligence than unmarried ones. Significant difference was also observed in emotional intelligence among student teachers when they were grouped according to marital status.

\section{Differences on Work Values Based on Demographic Variables}

Table II displays the differences on the work values based on the demographic variables. It shows that there are no gender differences in work values except in the area of Altruism.

This finding can be supported by previous multicultural study of Sta. Ana, Frega, and Sergio [23], when the work values such as Altruism have interplay with gender, especially among males. As Altruism is an intrinsic work values, the research findings of Wray-Lake, et al. [19] contradicts this result. Wray-Lake and associates reported that females considerably have greater willingness to work overtime and to work even if unnecessary for money than males. These findings are also consistent with work as cited in Schulenberg et al (1998) [9] and they fit with broader values literature wherein females consistently show a stronger orientation towards intrinsic pursuits and care orientations and males are more extrinsically-oriented .

The single and married CSRs differ only in Variety area of work values. Single CSRs have a higher mean score compared to those who are married. These findings are supported by Sta. Ana, Frega, and Sergio [23] which points to the data that the civil status significantly differs with work values, specifically Variety. This result elaborates that single workers would like to find new challenges and assortment of work compared to the nature of monotonous work that married workers prefer.

In terms of work time schedule on work values, it is shown that there are no significant differences. This denotes that the CSRs whose work time schedule is opposite or has a time difference of more than ten hours with the businesses they handle do not significantly relate with the overall work 
values of the respondents.

As for nationality, there are no significant differences in all work values area except on Security. Indians followed by Filipino CSRs have the highest mean scores as compared to CSRs of other nationalities. Compared with call center workers in other countries, Indians and Filipino CSRs are said to earn less considering that India and Philippines are some of the most preferred location for outsourcing jobs. Salamat [3] has justified, particularly, that because of Filipinos' fluency in the English language and their ability to copy Western culture they are preferred to be selected as CSRs. This notion is reflected in the findings as Indians and Filipinos seem to have common security issues. Valuing their jobs, they believe, is a gateway to be retained in their respective jobs.

TABLE II: DIFFERENCES ON WORK VALUES BASED ON DEMOGRAPHIC CHARACTERISTICS

\begin{tabular}{|c|c|c|c|c|c|}
\hline \multirow[t]{2}{*}{ Work Values } & & \multicolumn{4}{|c|}{ Demographic Variables } \\
\hline & & $\begin{array}{l}\text { Gend } \\
\text { er }\end{array}$ & $\begin{array}{l}\text { Civil } \\
\text { Statu } \\
\text { s }\end{array}$ & $\begin{array}{l}\text { Wor } \\
\mathbf{k} \\
\text { Time } \\
\text { Sche } \\
\text { d. } \\
\end{array}$ & $\begin{array}{l}\text { Nationalit } \\
\mathbf{y}\end{array}$ \\
\hline \multirow[t]{2}{*}{ Creativity } & $t$ & 1.081 & 857 & 1.041 & .530 \\
\hline & $p$ & .280 & .280 & .298 & .754 \\
\hline \multirow[t]{2}{*}{ Achievement } & $t$ & .702 & 1.453 & .216 & .410 \\
\hline & $p$ & .483 & .483 & .829 & .842 \\
\hline \multirow[t]{2}{*}{ Management } & $t$ & .086 & .663 & .680 & 1.392 \\
\hline & $p$ & .932 & .932 & .497 & .226 \\
\hline \multirow[t]{2}{*}{ Surroundings } & $t$ & 1.351 & .312 & 1.357 & .500 \\
\hline & $p$ & .177 & .177 & .175 & .776 \\
\hline \multirow[t]{2}{*}{ Sup. Rel. } & $t$ & 1.313 & .443 & .202 & .328 \\
\hline & $p$ & .190 & .190 & .840 & .896 \\
\hline \multirow[t]{2}{*}{ Way of life } & $t$ & 1.377 & 1.189 & 1.365 & .912 \\
\hline & $p$ & .169 & .169 & .173 & .473 \\
\hline \multirow[t]{2}{*}{ Security } & $t$ & .919 & .951 & 1.783 & 2.488 \\
\hline & $p$ & .359 & .359 & .075 & .031 \\
\hline \multirow[t]{2}{*}{ Associates } & $t$ & 1.896 & -.697 & -.842 & .656 \\
\hline & $p$ & .059 & .059 & .400 & .657 \\
\hline \multirow[t]{2}{*}{ Aesthetics } & $t$ & -.226 & .381 & -.702 & .576 \\
\hline & $p$ & .822 & .822 & .483 & .719 \\
\hline \multirow[t]{2}{*}{ Prestige } & $t$ & .614 & .894 & -1.106 & .665 \\
\hline & $p$ & .539 & .539 & .269 & .650 \\
\hline \multirow[t]{2}{*}{ Independence } & $t$ & -.483 & 1.639 & -.845 & .280 \\
\hline & $p$ & .629 & .629 & .398 & .924 \\
\hline \multirow[t]{2}{*}{ Variety } & $t$ & .445 & 2.347 & -.722 & .798 \\
\hline & $p$ & .657 & .657 & .471 & .552 \\
\hline \multirow{2}{*}{$\begin{array}{l}\text { Economic } \\
\text { return }\end{array}$} & $t$ & .356 & 1.189 & -.222 & .193 \\
\hline & $p$ & .722 & .722 & .825 & .965 \\
\hline \multirow[t]{2}{*}{ Altruism } & $t$ & 2.453 & .523 & .919 & 1.481 \\
\hline & $p$ & .015 & .015 & .359 & .195 \\
\hline Intel. & $t$ & .287 & .113 & -.243 & 1.726 \\
\hline Stimulation & $p$ & .775 & .775 & .808 & .127 \\
\hline
\end{tabular}

\section{Correlation between Emotional Intelligence and Work Values}

Table III illustrates the correlation between emotional competence and work values. The first emotional intelligence cluster which is Self Awareness or the ability to manage one's internal states, impulses and resources has a negative relationship with all areas of work values. This means that the CSRs are not able to recognize their emotions and its impact on them, the strengths and limitations they have and their self-worth, the more they will not be able to value their work in all its dimensions.

The second emotional intelligence cluster which is Self Management or the ability manage ones' internal states, impulses, and resources that contains six competencies: emotional self-control, transparency, adaptability, achievement, initiative, optimism has significant relationship with some areas of work values such as Management, Achievement, Supervisory Relations, Way of Life, Independence, and Altruism. The result implies that the more that the CSRs are in control of their emotions, the more they can perform on their jobs and the more efficient they can function as a supervisor or manager in the workplace being unconditionally dedicated. Moreover, as an implication, CSRs have to manage their emotions because of the nature of their stressful work. They have to control their temper when encountering irate callers and this result to emotional dissonance.

TABLE III: CORRELATION BETWEEN EMOTIONAL INTELLIGENCE AND WORK VALUES

\begin{tabular}{|c|c|c|c|c|c|c|}
\hline \multirow[t]{2}{*}{ Work Values } & & \multicolumn{5}{|c|}{ Emotional Intelligence } \\
\hline & & $\begin{array}{l}\text { Self } \\
\text { Aware } \\
\text {. }\end{array}$ & $\begin{array}{l}\text { Self } \\
\text { Mg't. }\end{array}$ & $\begin{array}{l}\text { Social } \\
\text { Aware } \\
\text {. }\end{array}$ & $\begin{array}{l}\text { Relat. } \\
\text { Mg't. } \\
\text { Overall }\end{array}$ & ECI \\
\hline \multirow[t]{2}{*}{ Creativity } & $r$ & .029 & .048 & .089 & .089 & .082 \\
\hline & $p$ & .544 & .313 & .064 & .064 & .089 \\
\hline \multirow[t]{2}{*}{ Management } & $r$ & .056 & .114 & .057 & .119 & .111 \\
\hline & $p$ & .244 & .017 & .237 & .013 & .021 \\
\hline \multirow[t]{2}{*}{ Achievement } & $r$ & .050 & .107 & .120 & .125 & .128 \\
\hline & $p$ & .294 & .025 & .012 & .009 & .007 \\
\hline \multirow[t]{2}{*}{ Surroundings } & $r$ & -.011 & -.044 & -.020 & -.049 & -.040 \\
\hline & $p$ & .814 & .360 & .672 & .311 & .402 \\
\hline \multirow[t]{2}{*}{ Sup. Relation. } & $r$ & .074 & .127 & .194 & .100 & .155 \\
\hline & $p$ & .123 & .008 & .000 & .037 & .001 \\
\hline \multirow[t]{2}{*}{ Way of life } & $r$ & .076 & .113 & .108 & .037 & .103 \\
\hline & $p$ & .114 & .018 & .024 & .442 & .031 \\
\hline \multirow[t]{2}{*}{ Security } & $r$ & .020 & .072 & .096 & .053 & .075 \\
\hline & $p$ & .680 & .133 & .044 & .270 & .116 \\
\hline \multirow[t]{2}{*}{ Associates } & $r$ & -.073 & -.012 & .000 & -.014 & -.033 \\
\hline & $p$ & .128 & .795 & .993 & .773 & .489 \\
\hline \multirow[t]{2}{*}{ Aesthetics } & $r$ & -.048 & .083 & .122 & .086 & .075 \\
\hline & $p$ & .315 & .083 & .011 & .072 & .118 \\
\hline \multirow[t]{2}{*}{ Prestige } & $r$ & .010 & .076 & .077 & .059 & .069 \\
\hline & $p$ & .830 & .111 & .106 & .215 & .148 \\
\hline \multirow[t]{2}{*}{ Independence } & $r$ & .062 & .119 & .103 & .069 & .110 \\
\hline & $p$ & .195 & .012 & .031 & .148 & .021 \\
\hline \multirow[t]{2}{*}{ Variety } & $r$ & .025 & .126 & .082 & .030 & .080 \\
\hline & $p$ & .606 & .008 & .088 & .528 & .096 \\
\hline \multirow[t]{2}{*}{ Eco. Return } & $r$ & .000 & .018 & .008 & .057 & .027 \\
\hline & $p$ & 1.000 & .713 & .866 & .238 & .568 \\
\hline \multirow[t]{2}{*}{ Altruism } & $r$ & .012 & .108 & .087 & .050 & .079 \\
\hline & $p$ & .802 & .024 & .069 & .296 & .099 \\
\hline \multirow[t]{2}{*}{ Intel. Stimula. } & $r$ & -.015 & .037 & -.023 & -.016 & -.007 \\
\hline & $p$ & .752 & .445 & .625 & .736 & .884 \\
\hline
\end{tabular}

The third emotional intelligence cluster is Social Awareness or how people handle relationships and awareness of others' feelings and needs has a significant relationship with work values, specifically with Achievement, Supervisory Relations, Way of Life, Security, Aesthetics, and Independence. This result showcases that the more call center workers can show empathy, recognize the emotions of their work group, as well as anticipate, recognize and meet the needs of the customers, the more they will be able to value work through leadership without restraint. 
The fourth emotional intelligence cluster which is Relationship Management concerns the skill or adeptness at inducing desirable responses in others also possesses significant relationship with work values, particularly with Management, Achievement, and Supervisory Relations. It is so because the CSRs' work is stressful in so many ways and they need to show teamwork, collaboration, leadership, and to meet targets through collective efforts, manage change, and resolve conflicts. Thus, a high EI is likely to help boost work values.

It can be gleaned from the table that the overall emotional intelligence clusters and dimensions significantly relate to work values such as Management, Achievement, Supervisory Relations, Way of Life, and Independence. These findings point that the higher the work values pertaining to interest to lead and exercise autonomy, the more emotionally intelligent the CSRs are. Furthermore, they can manage their own emotions and can relate well with people around them, recognizing common rules as essential to their individual roles, and be able to contribute without being directed. The results are supported by Bradzil \& Slaski [34] when he pointed out that people with high EQ are more grounded, more resilient and are more satisfied at work; they display empathy, are adaptable and able to cope with pressure and generally experience less stress and better health and well-being than low scorers.

\section{CONCLUSION}

The emotional intelligence of CSRs is influenced by gender, civil status, nationality, and work schedule. Findings also revealed that the demographic variables such as gender, civil status, and nationality significantly impact work values but not in the case of work time schedule.

CSRs who are male, single, as well as those whose work time schedule is opposite are more emotionally competent that their counterparts. Russians were found to be emotionally aware, self-confident, and capable of assessing self accurately as well as good at managing the self. Indians and Filipino CSRs were found to be emotionally competent in handling relationships, conscious of others' feelings and needs as well as skilled at inducing desirable responses in others.

Based on the findings of the study, it can be concluded that emotional intelligence plays an important role in specific areas of work values (Management, Achievement, Supervisory Relations, Way of Life, and Independence) among CSRs.

\section{IMPLICATIONS/RECOMMENDATIONS}

In the light of the foregoing findings and conclusions, the recommendations below are presented to help improve the call center organizations towards organizational change.

The researchers believe that the organizations involved in the study are constantly changing its practices depending on its response to markets conditions, process improvements, among others and these have impact on the internal customers' work values. The emotional competencies required in coping with conflicts that involve in work and work values remain to be a concern. This study has pointed on three-dimensional programs that can help organizations involved in the study cope with change in multicultural environment:

\section{A. Soft Skills Training Program}

As the results showcase that most CSRs are not able to recognize their emotions and its impact on them, there is a need for Soft Skills Training Program, particularly the Self-Awareness, Self Management, Social Awareness, and Relationship Management Programs. This set of training programs may be a series of seminar-workshops that enhance emotional intelligence, particularly personal competence for Indians and Filipinos and social competence for Russians and Middle East nationals. The strategic purpose of such program is to provide the employees in the organization with the right soft skills, tools and techniques required for them to perform their role effectively as the changes in multicultural environment of the CSRs in the study.

\section{B. Communications Program}

The CSRs from the Middle East, Iran, Pakistan, Russia, India, and the Philippines have something in common: The constant use of communication technology as part of globalization. Any change management efforts will be futile if the organization fails to employ the carefully structured communication mechanisms to inform internal customers about certain development efforts. Knowing that these CSRs interact with external and internal customers, communication is always viewed as a vital component to the overall change management program. Detailed resources are highly recommended for organizations in this study as they manage change. For instance, communications tool kits for managers and team head shall be made available for both physical and online facilities as a form of professional and social support.

\section{Closing the Loop Management Program}

By "closing the loop", the call center organizations involved in this study actively monitor feedback on the planned changes. The first dimension (Soft Skills Training Program) is the core of implementation whilst the second dimension (Communications Program) supports the entire organizational intervention. The identification of resistance, validated surveys to describe effectiveness during implementation, and ways to combat all sorts barriers encountered are some of the efficient ways to effectuate change in the organizations involved in this study.

\section{REFERENCES}

[1] D. Zapf, A. Isic, M. Bechtoldt, and P. Blau, "What is typical for call centre jobs? Job characteristics and service interactions in different call centres," European Journal of Work and Organizational Psychology, vol. 12, no. 4, pp. 311-340, 2003.

[2] B. Russell, "Call centers: A decade of research," International Journal of Management Reviews, vol. 10, no. 3, pp. 195-219, 2008.

[3] M. Salamat. (December 2010). Call center employees in the Philippines receive low-end jobs, low salaries. [Online]. Available: http://www.voxbikol.com

[4] S. Grebner, N. Semmer, L. Faso, S. Gut, W. Kälin, and A. Elfering, "Working conditions, well-being, and job-related attitudes among call centre agents," European Journal of Work and Organizational Psychology, vol. 12, no. 4, pp. 341-365, 2003. 
[5] S. Deery, R. Iverson, and J. Walsh, "Coping strategies in call centres: Work intensity and the role of co-workers and supervisors," British Journal of Industrial Relations, vol. 48, no. 1, pp. 181-200, 2010.

[6] D. Goleman, Working with Emotional Intelligence, New York: Bantam Books, Hay/McBer, 2000.

[7] L. Lu and G. C. Lin. (2002). Work Values and job adjustment of Taiwanese workers. Research and Practice in Human Resource Management. [Online]. 10(2). pp. 70-76. Available: http://rphrm.curtin.edu.au/2002/issue2/values.html.

[8] S. H. Schwartz, "Universals in the content and structure of values: Theory and empirical tests in 20 countries," Advances in Experimental Social Psychology, in M. Zanna (Ed.), vol. 25, pp. 1-65, 1992.

[9] J. E. Schulenberg, F. W. Vondracek, and J. R. Nesselroade, "Patterns of short-term changes in individuals' work values: P-technique factor analyses of intra-individual variability," Multivariate Behavioral Research, vol. 23, pp. 377-395, 1998.

[10] J. Selmer and C. D. Leon, "Parent cultural control through organizational acculturation: MCN employees learning new work values in foreign business subsidiaries," Journal of Organizational Behavior, vol. 17, pp. 557-572, 1996.

[11] MOW International Research Team, "The meaning of working: An eight," Country Comparative Study, London: Academic Press, 1987.

[12] B. Šverko, "Origin of individual differences in importance attached to work: A model and a contribution to its evaluation," Journal of Vocational Behavior, vol. 34, pp. 28-39, 1989.

[13] S. B. Wolff. (2005). Emotional Competence Inventory (ECI) Version 2.0 Technical Manual. [Online]. Available: http://www.eiconsortium.org/pdf/ECI_2_0_Technical_Manual_v2.pd f.

[14] Z. Allam, "Emotional intelligence at workplace: A psychological review," Global Management Review, vol. 5, issue 2, 2011.

[15] C. Cherniss and D. Goleman, The Emotionally Intelligent Workplace, San Fransisco, Jossey-Bass, 2001, pp. 28-39.

[16] R. K. Cooper and A. Sawaf, Executive EQ: Emotional Intelligence in Leaders and Organizations, Grosset/Putnam, NY, 1997, pp. 67-79.

[17] R. P. Sergio, "The software component of the mind vis-à-vis job performance: Perspectives and implications," International Review of Social Sciences and Humanities, vol. 1, pp. 75-83, May 2011.

[18] M. Rokeach, The Nature of Human Values, New York: Free Press, 1973.

[19] L. W. Lake, A. K. Svertsen, L. Briddel, D. W. Osgood, and C. A. Flanagan. (2009). Exploring the changing meaning of work for American high school seniors from 1976 to 2005. [Online]. Available: http://yas.sagepub.com/content/43/3/1110.

[20] D. E. Super, Manual for the Work Value Inventory, Houghton Mifflin, Boston, 1970.

[21] M. Ross, S. Schwartz, and S. Surkiss. (1999). Basic Individual Values, Work Values, and the Meaning of Work. [Online]. Available: http://www.choixdecarriere.com/pdf/6573/2010/RosSchwartzSurkiss1 999.pdf

[22] R. A. Roe and P. Ester, "Values and work: Empirical Findings and Theoretical Perspective," Applied Psychology: An International Review, vol. 48, no. 1, pp. 1-21, 1999.

[23] A. S. Ana, D. Frega, and R. Sergio, "The work values of young professionals in a multicultural environment," presented at the 8th International Conference on Interdisciplinary Social Sciences, Prague, Czech Republic, July 31-August 1, 2013.

[24] J. W. Kwon. (2007). Work Values, Organizational Structure, and Job Structure among Korean, British, and American Multinational Banks in Korea: Employees' Nationalities vs. MNC's Nationalities. [Online]. Available:

http://businesscommunication.org/wp-content/uploads/2011/04/12AB CAsiaPac07.pdf.

[25] W. R. A. Rahman. Research on work values in Malaysia and Thailand: A cross-cultural research proposal. [Online]. Available: http://bsris.swu.ac.th/iprc/4th/25.pdf.

[26] Understanding the importance of work: the effects of work values and work-value congruence. [Online]. Available: http://www.wu.ac.at/iaccm/files/iaccm09/pa/ucanok.pdf

[27] Z. K. Aygün and E. O. Imamoglu, "Value domains of Turkish adults and university students," The Journal of Social Psychology, vol. 142, no. 3, pp. 333-351, 2002.

[28] B. M. Meglino and E. C. Ravlin. (1998). Individual values in organizations: Concepts, controversies and research. Journal of Management. [Online]. 24(3), pp. 351-389. Available: http://faculty.washington.edu/mdj3/MGMT580/Readings/Week\%205/ Meglino.pdf
[29] D. G. Zytowski. Super's work values inventory. Version 1.2 Technical Manual. [Online]. Available: http://www.kuder.com/downloads/SWV-Tech-Manual.pdf.

[30] N. Uyguç and B. D. M. S. Cinsiyet, Dokuz Eylül Üniversitesi Đktisadi Đdari Bilimler Fakïltesi Dergisi, vol. 18, no. 1, pp. 93-103, 2003.

[31] H. S. Pande, "Evaluating characteristics and emotional intelligence among workers in organizations in the state of Rajasthan," International Research Journal, vol. 1, issue 10, 2010.

[32] K. Cavallo and D. Brienza. (2002). Emotional Competence and Leadership Excellence at Johnson and Johnson: The Emotional Intelligence Leadership Study. [Online]. Available: http://www.eiconsortium.org

[33] A. Ealias and J. George, "Emotional intelligence and job satisfaction: A Correlational study," The International Journal's Research Journal of Commerce and Behavioral Science, 2012.

[34] P. Bardzil and M. Slaski, "Emotional intelligence: Fundamental competencies for enhanced service provision," Managing Service Quality, vol. 13, no. 2, pp. 97-104, 2003.

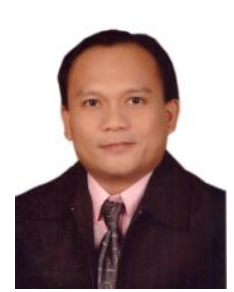

Rommel Pilapil Sergio was born in Baras, Rizal, Philippines in 1974. He is a member of the International Economics Development and Research Center. He holds a Post-Doctoral Bridge to Business in Management certificate at Tulane University, New Orleans, Louisiana, USA in 2011 and has earned his $\mathrm{PhD}$ in Psychology (summa cum laude) at De La Salle University, Philippines in 2008. He is currently the Human Resource Management Program Chair and Assistant Professor at the Canadian University of Dubai, United Arab Emirates. Prior to university teaching, it can be noted that he has served various multinational companies as HR Manager then later on as Organizational Development Consultant in the Philippines and in abroad.

He has published articles in several refereed journals; and has served as an editor-reviewer at The Asian Journal of Sciences and Humanities, The International Journal of Business and Management Research, Asian Journal of Business and Governance; and The International Review of Social Sciences and Humanities. His research interests include emotional intelligence, work values, work-family conflict, job performance, cross-cultural orientations, and talent management.

It can be noted that Dr. Sergio was awarded the 2013 Most Outstanding Faculty in Research Award at CUD. Moreover, he was certified by the AACSB (The Association to Advance Collegiate Schools of Business) in Florida, USA as AQ (Academically Qualified) to teach in Management.

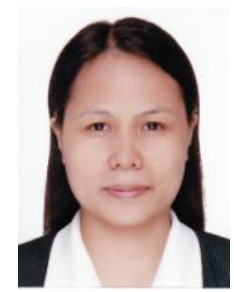

Antonette Lazaro Dungca was born in Tarlac, Philippines in 1976. She is a Ph.D. in Psychology candidate at the University of the Philippines. In 2003, she obtained her Master of Arts in Industrial Psychology from the Pamantasan ng Lungsod ng Maynila in 2003 and her Bachelor of Science in Psychology at the Far Eastern University (FEU), Manila in 1996 where she graduated cum laude.

She is the Deputy Director of the University of the Philippines Institute for Small Scale Industries (UP ISSI) and the Head of the Entrepreneurship Research and Development Department of the said institution. She is also a Special Lecturer (part-time) of Department of Psychology Graduate School of Far Eastern University handling major subjects such as Organization Development, Clinical Psychology, Research Methods in Psychology, Psychological Testing and Psychological Measurement. Prior to her present position at UPISSI, she was appointed as Head of the Planning and Research Division of the University of the Philippines-Human Resources Development Office (UP-HRDO) from 2008 to 2011. After graduation in college, she was invited to teach psychology subjects at the Department of Psychology at Far Eastern University where she served as a full time faculty member from 1997 to 2002 .

Dungca was a recipient of the American Psychological Association (APA) International Travel Award and participated in the conference held in San Francisco, California USA in 2007. In 2004, Dungca presented her paper entitled "Adversity Quotient and Performance Level of Middle Managers of the City of Manila" at the Industrial Relations Regional Association Conference held in Seoul, Korea. 


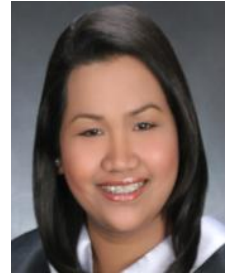

Luzelle Anne Gonzales-Lim Ormita was born in Manila, Philippines in1976. She took her Bachelor of Science in Psychology at the Far Eastern University (FEU), Manila and graduated cum laude in1996. Further, she obtained her Master of Arts in Industrial Psychology from the Pamantasan ng Lungsod ng Maynila in 2004 and is a Ph.D. in Psychology candidate at the University of the Santo Tomas, currently into her dissertation writing. he is an Associate Professor at FEU where she has been teaching for the past sixteen years. She has handled a number of major subjects such as Research in Psychology, Experimental Psychology, Psychological Testing, Industrial Psychology and Practicum. From 2003 to 2011, she has served as the Practicum Coordinator of the same department, where she assisted undergraduate trainees in their apprenticeship program. At present, she is the Program Coordinator of the Department of Psychology at FEU, Manila.
Ormita is a consistent recipient of the FEU Teaching Excellence Award and is also active in community extension projects. She utilizes her skills and expertise in psychology in rendering volunteer work with underprivileged communities, out-of-school youth and prisoners. Her research interests are in line with adolescent and incarceration studies, test development, and in the areas of educational and industrial/organizational psychology. She presented her paper entitled "Predictors of Internship Satisfaction among FEU Psychology Students" at the fourth ASEAN Union of Psychological Societies held in Manila, Philippines in 2013. One of her published works is entitled "The Psychological Profile of Incarcerated Women under the FEU-Project HOPE: A Multiple Case Study." 